\title{
ANALYSIS OF FACTORS THAT AFFECTS THE INVESTORS IN CONDUCTING BUSINESS IN INDONESIA
}

\author{
Rini Kurnia Sari \\ Management Department, School of Business Management, BINUS University \\ Jln. K.H. Syahdan No.9, Palmerah, Jakarta Barat 11480 \\ rini@binus.ac.id; rini_kurnia_sari@yahoo.com
}

\begin{abstract}
Investment is needed in the development of the economy. With the decentralization of investment is expected to evolve as a whole in every province in Indonesia. Local governments need to improve the quality of economic (GDP / Capita), social (HDI) and the infrastructure to attract domestic and foreign investors. Fromthe test results showed that factors affecting investors conducting business in Indonesia is still influenced by GDP/capita, HDI and Infrastructure instead of natural resources.This study uses descriptive analysis and correlation analysis methods to look at the correlation factors that affect investors doing business in Indonesia.
\end{abstract}

Keywords: investment, GDP/capita, HDI, infrastructure

\begin{abstract}
ABSTRAK
Investasi merupakan salah satu yang dibutuhkan dalam pembangunan ekonomi.Dengan adanya otonomi daerah diharapkan investasi berkembang secara menyeluruh di setiap Provinsi di Indonesia.Pemerintah daerah harus memperbaiki kualitas ekonomi (PDRB/Kapita), sosial (IPM) dan infrastruktur untuk menarik investor domestik maupun asing. Dari hasil pengujian didapatkan bahwa faktor yang mempengaruhi investor melakukan kegiatan bisnis di Indonesia masih dipengaruhi oleh PDRB/Kapita, IPM dan Infrastruktur bukan sumberdaya alam.Penelitian ini menggunakan metode analisis deskriptif dan metode analisis korelasi untuk melihat korelasi faktor-faktor yang mempengaruhi investor melakukan kegiatan bisnis di Indonesia.
\end{abstract}

Kata kunci:investasi, PDRB/Kapita, IPM, infrastruktur 


\section{PENDAHULUAN}

Kinerja perekonomian Indonesia terlihat masih terjaga dengan baik melalui pertumbuhan ekonomi yang cukup tinggi walaupun kondisi perekonomian dunia sepanjang tahun 2010-2012 dalam tekanan yang cukup berat. Pada tahun 2012 pertumbuhan ekonomi Indonesia mencapai 6,2 persendan pada tahun 2011 pertumbuhannya mencapai 6,5 persen. Kinerja nasional yang sangat baik ini tentu ditunjang oleh investasi yang semakin meningkat.Dalam kerangka pembangunan secara keseluruhan, investasi menghasilkan banyak dampak ganda (multiplier effects) dan memberi manfaat bagi banyak pihak seperti perusahaan, masyarakat dan pemerintah. Laju pertambahan investasi dan tingkat produktivitas yang dihasilkanakan mendorong jangkauan dampak yang ditimbulkan. Dengan adanya momentum kinerja perekonomian nasional yang sangat baik ini, maka diharapkaninvestasi berkembang secara menyeluruh di setiap Provinsi di Indonesia.

Pemerintah daerah harusgiat mengembangkan daerahnya sebagai tujuan investasi.Bentuk dan upaya menciptakan daya tarik investasi di setiap daerah sangat beragam.Mulai dari membuat slogan yang indah, mengekspos perjanjian kerjasama, memberikan kepastian keamanan, pembangunan sistem pelayanan penanaman modal (Simpedal) dan penyelesaian urusan administrasi penanaman modal melalui satu atap atau satu pintu (one stop service).Beberapa daerah bahkan menciptakan Peraturan Daerah (Perda) yang bertujuan untuk meningkatkan daya tarik investasi masuk.

Otonomi daerah di satu sisi telah memberikan peluang yang cukup besar kepada daerah untuk menarik investasi swasta sebagai salah satu sumberpembiayaan pembangunan.Namun demikian, peluang tersebut juga telah menciptakan persaingan yang semakin tajam antara daerah dalam menarik investasikedaerah masing-masing.Persainganyangsehat mengharuskan pemerintah daerah menyiapkan segala macam yang terbaik untuk menarik investasi, orang dan industri untuk masuk ke wilayah masing-masing.

Pemerintah Provinsi (Pemprov) tetap memegang tanggung jawab dalam penciptaan iklim investasi di wilayahnya.Peran penting Pemprov terutama adalah merumuskan perencanaan kebijakan bidang investasi di level provinsi.Pemprov adalah perencana pembangunan ekonomi regional dan perencana tata ruang Provinsi sesuai dengan tanggung jawab sebagai koordinator aktivitas ekonomi yang bersifat lintas kabupatan/kota termasuk di dalamnya pelayanan di bidang investasi.

Iklim usaha tersebut dipengaruhi oleh berbagai faktor kompleks yang terkait satu sama lain dengan derajat pengaruh berbeda antar faktor. Dalam survei yang dilakukan oleh Komite Pemantauan Pelaksanaan Otonomi Daerah (KPPOD) dan Badan Koordinasi Penanaman Modal (BKPM) pada tahun 2008 ditetapkan sembilan indikator survei pemeringkatan iklim usaha Provinsi, yaitu kelembagaan pelayanan penanaman modal, promosi investasi daerah, komitmen pemda, infrastruktur, akses lahan usaha, tenaga kerja, keamanan usaha, kinerja ekonomi daerah, dan peranan dunia usaha dalam perekonomian daerah.

Banyak faktor yang mempengaruhi investor melakukan kegiatan bisnis di suatu daerah.Keterbatasan waktu membuat penelitian harusberfokus pada pengaruh faktor PDRB/Kapita, IPM dan infrastruktur terhadap keputusan investor menanamkan modalnya di Indonesia.

\section{Faktor-Faktor yang Mempengaruhi Investasi}

Indikator ekonomi suatu daerah, seperti Produk Domestik Regional Bruto(PDRB), indikator sosial-ekonomi seperti Indeks Pembangunan Manusia (IPM) dan infrastruktur, merupakan lingkungan makro yang berdampak signifikan bagi produktivitas usaha. Sehingga investasi akan meningkat jika pertumbuhan perekonomian suatu daerah tinggi (PDRB), kualitas sumber daya manusia baik (IPM) dan infrastruktur yang ada di daerah tersebut tersedia dengan baik. 
Faktor pertama, PDRBper kapita merupakan cermin dari daya beli masyarakat atau pasar.Semakin tinggi daya beli masyarakat suatu negara atau daerah (yang dicerminkan oleh pendapatan nasional per kapita atau PDRB per kapita) maka akan makin menarik investor dalam negeri maupun asing untuk berinvestasi. Kedua, kualitas sumberdaya manusia.Manusia yangberkualitas akhir-akhir ini merupakan daya tarik investasi yang cukup penting karena teknologi yang dipakai oleh para pengusaha makinlama makin modern.Teknologi modern tersebutmenuntut keterampilan lebih dari tenaga kerja dan kualitas sumber daya manusia ini diukur oleh IPM (Indeks Pembangunan Manusia).Ketiga, kondisi infrastruktur yang baik.Investasi membutuhkan infrastruktur pendukung dalam menjalankan semua kegiatan bisnis.

\section{Investasi}

Investasi adalah setiap wahana tempatdana diinvestasikan dengan harapan dapat memelihara atau menaikkan nilai dan memberikan hasil (return) yang positif.Sumber investasi berasal dari investasi domestik dan investasi asing.Investasi domestik merupakan investasi yang berasal dari dalam negeri, sedangkan investasi asing merupakan investasi yang berasaldariluarnegeri.Sukirno (2010) menyatakan bahwa investasi adalah pengeluaran pembelanjaan penanam-penanam modal atau perusahaan untuk membeli barang-barang modal dan perlengkapan-perlengkapan produksi untuk menambah kemampuan produksi barang dan jasa yang tersedia dalam perekonomian.

\section{Produk Domestik Regional Bruto (PDRB)}

PDRB merupakan nilai barang dan jasa akhir yang dihasilkan oleh unit-unit produksi di suatu wilayah atau region dalam suatu periode tertentu.PDRB perkapita adalah total PDRB di bagi dengan jumlah penduduk pada periode tertentu.

Penelitian yang dilakukanSodikdanNuryadin (2005) menggunakan data runtutan waktu (time series) dari tahun 1998-2004 dan data cross section dari 26 provinsi di Indonesia. Hasil analisis data menunjukkan selama priode penelitian ditemukan bahwa variabel PMDN berpengaruh terhadap pertumbuhan ekonomi regional (PDRB), sehingga investasi (baik PMA maupun PMDN) sangat diperlukan oleh suatu daerah untuk tumbuh dan berekembang sesuai kemampuannya sendiri.

Penelitian yang dilakukan Ali dan Guo (2005) menemukan bahwa ukuran pasar pontesial dan pertumbuhan ekonomi China yang cepat adalah faktor yang paling signifikan bagi FDI inflow di China.

\section{Indeks Pembangunan Manusia (IPM)}

Manusia adalah kekayaan bangsa yang sesungguhnya.Tujuan utama dari pembangunan adalah menciptakan lingkungan hidup yang memungkinkan bagi rakyatnya untuk menikmati umur panjang, sehat dan menjalankan kehidupan yang produktif.Hal ini tampaknya merupakan suatu kenyataan sederhana, tetapi hal ini seringkali terlupakan oleh berbagai kesibukan jangka pendek untuk mengumpulkan harta dan uang.United Nations Development Programme (UNDP, 1995) mendefinisikan bahwa pembangunan manusia sebagai suatu proses untuk memperluas pilihan-pilihan bagi penduduk dalam hal pendapatan, kesehatan, pendidikan, lingkungan fisik, dan sebagainya.

\section{Infrastruktur}

Infrastrukturmerupakan sarana dan prasarana yang mendukung kegiatan ekonomi.Infrastruktur meliputi transportasi, komunikasi, utilitas, pembuangan limbah dan lain-lain.Sarana transportasi adalah jalan, terminal, pelabuhan, bandar udara dan lain-lain.Sarana dan prasarana telekomunikasi adalahjaringan teleponkabel maupun nirkabel, jaringan internet, prasarana dan sarana pos. Sedangkan sarana utilitas adalah tersedianyaairbersih, listrikdan lain-lain. 
Suatu proses pembangunan ekonomi yang telah lama berlangsung dan telah menghasilkan pertumbuhan ekonomi yang tinggi biasanya menghasilkan suatu perubahan mendasar dalam struktur ekonomi. Perubahan stuktur ekonomi terjadi akibat perubahan sejumlah faktor, salah satunya adalah infrastruktur (Tambunan, 2001).

\section{METODE}

Metode penelitian yang digunakan adalah metode analisis deskriptifdankorelasi.Metode analisis deskriptif dilakukan dengan cara mendeskripsikan data yang sudah dikumpulkan untuk menemukan unsur-unsurnya dan kemudian dianalisis dan diperbandingkan.Metode korelasi meneliti hubungan atau pengaruh sebab akibat antar variabel-variabel yang berbeda dalam suatu populasi. Untuk memudahkan semua proses, analisis ini menggunakan software Excel 2010.

\section{HASIL DAN PEMBAHASAN}

Selama tahun 2010 sampai tahun 2012 daerah tujuan investasi di daerah hanya berfokus padaPulau Jawa.Data menunjukkan sebesar 60\% investasi hanya berada di Pulau Jawa dan ini berarti tidak adanya distribusi investasi secara merata di Indonesia.
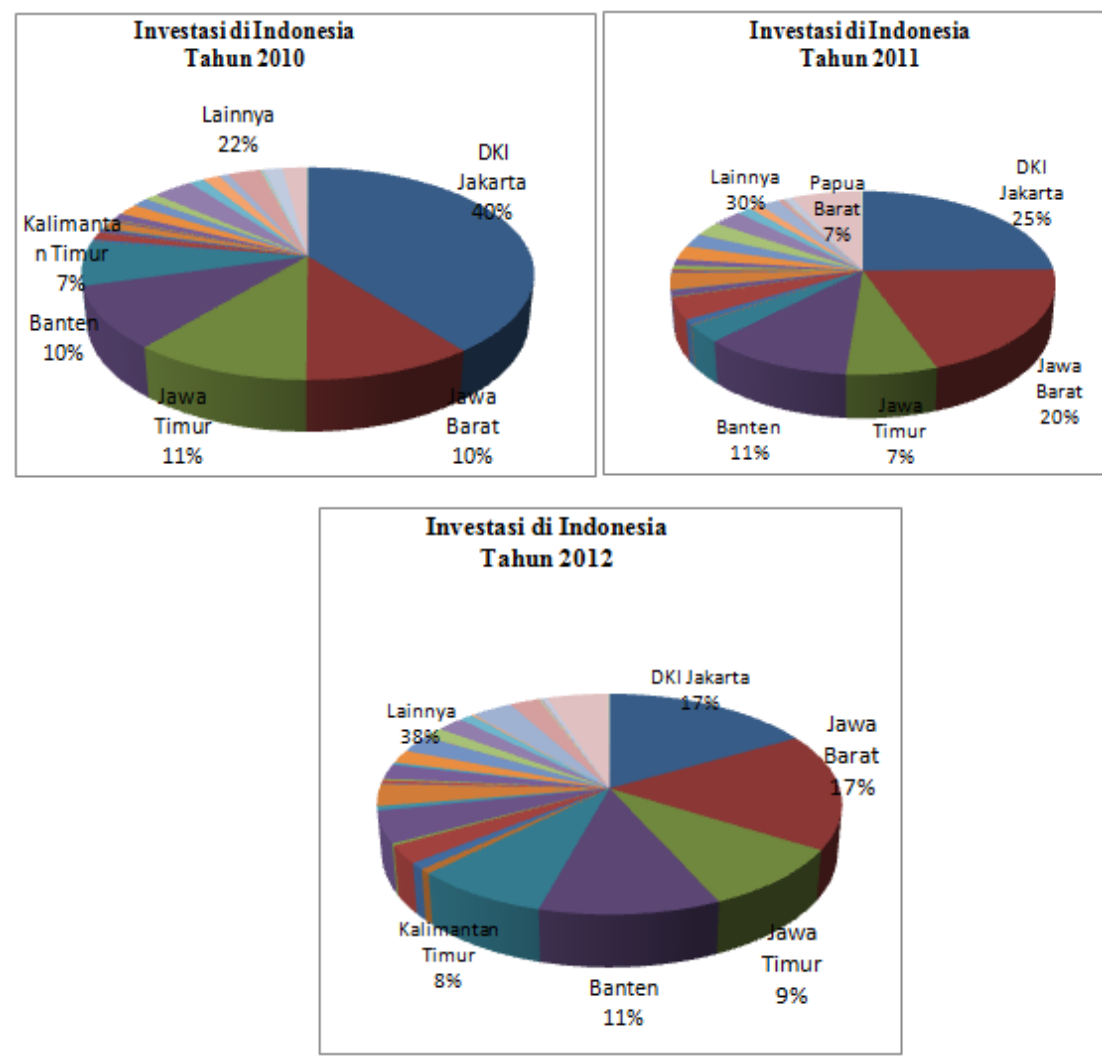

Gambar 1 Investasi di Indonesia

Sumber data: Badan Koordinasi Penanaman Modal (BKPM)

Persentase terbesar investasi di Indonesia berada di DKI Jakarta dan selanjutnya diikuti oleh Jawa Barat, Jawa Timur dan Banten dan selanjutnya Bali, Jawa Tengah, Jawa Timur, Sulawesi Utara, 
Sulawesi Selatan, Banten, DIY dan seterusnya. Sementara tiga wilayah dengan persentase terbawah ada di daerah-daerah di luar Pulau Jawa, seperti Gorontalo, Nusa Tenggara Timur dan Maluku dengan nilai investasi kurang dari 1\% dari total investasi di Indonesia.

\section{Analisis Hubungan antara Investasi dengan PDRB/Kapita, IPM dan Infrastruktur}

PDRB/Kapita memiliki hubungan yang positif dengan Investasi.Semakin tinggi PDRB/Kapita, maka nilai investasi semakin tinggi.IPM memiliki hubungan yang positif dengan investasi.Semakin tinggi IPM, maka nilai investasi semakin tinggi.Infrastruktur memiliki hubungan yang positif denganinvestasi.Semakin baik infrastruktur, maka nilai investasi semakin tinggi.

Tabel 1Nilai Korelasi Investasi dengan PDRB/Kapita, IPM dan Infrastruktur

\begin{tabular}{clcc}
\hline \multirow{2}{*}{ No. } & \multicolumn{1}{c}{ Provinsi } & \multicolumn{2}{c}{ Nilai Korelasi } \\
\cline { 3 - 4 } & & $\begin{array}{c}\text { Investasi - } \\
\text { PDRB/Kapita }\end{array}$ & $\begin{array}{c}\text { Investasi - } \\
\text { IPM }\end{array}$ \\
\hline 1 & Aceh & 0,949 & 0,930 \\
2 & Sumatera Utara & 0,897 & 0,883 \\
3 & Sumatera Barat & 0,965 & 0,974 \\
4 & Riau & 0,999 & 0,999 \\
5 & Kepulauan Riau & 0,999 & 0,983 \\
6 & Jambi & 0,967 & 0,976 \\
7 & Sumatera Selatan & 0,988 & 0,978 \\
8 & Kepulauan Bangka & 0,538 & 0,504 \\
9 & Belitung & 0,689 & 0,686 \\
10 & Bengkulu & 0,814 & 0,791 \\
11 & Dampung & $-0,971$ & $-0,973$ \\
12 & Jawa Jakarta & 0,979 & 0,985 \\
13 & Banten & 0,983 & 0,989 \\
14 & Jawa Tengah & 0,999 & 0,996 \\
15 & DI. Yogyakarta & 0,828 & 0,814 \\
16 & Jawa Timur & 0,821 & 0,829 \\
17 & Bali & 0,999 & 0,993 \\
\hline
\end{tabular}

\begin{tabular}{llcc}
\hline \multirow{2}{*}{ No. } & \multicolumn{1}{c}{ Provinsi } & \multicolumn{2}{c}{ NilaiKorelasi } \\
\cline { 3 - 4 } & & $\begin{array}{c}\text { Investasi - } \\
\text { PDRB/Kapita }\end{array}$ & $\begin{array}{c}\text { Investasi - } \\
\text { IPM }\end{array}$ \\
\hline 18 & Nusa Tenggara Barat & 0,225 & 0,892 \\
19 & Nusa Tenggara Timur & 0,982 & 0,978 \\
20 & Kalimantan Barat & 0,917 & 0,917 \\
21 & Kalimantan Tengah & 0,751 & 0,731 \\
22 & Kalimantan Selatan & 0,972 & 0,988 \\
23 & Kalimantan Timur & 0,339 & 0,484 \\
24 & Sulawesi Utara & $-0,794$ & $-0,766$ \\
25 & Gorontalo & 0,956 & 0,938 \\
26 & Sulawesi Tengah & 0,986 & 0,980 \\
27 & Sulawesi Selatan & 0,232 & 0,219 \\
28 & Sulawesi Barat & 0,860 & 0,924 \\
29 & Sulawesi Tenggara & $-0,857$ & $-0,896$ \\
30 & Maluku & 0,655 & 0,657 \\
31 & Maluku Utara & $-0,811$ & $-0,836$ \\
32 & Papua & $-0,999$ & 0,751 \\
33 & Papua Barat & 0,937 & 0,880 \\
\hline
\end{tabular}
berikut:

Menurut Sugiyono (2007) pedoman untuk memberikan interpretasi koefisien korelasi sebagai

Tabel 2 Korelasi

\begin{tabular}{|c|c|c|}
\hline \multicolumn{2}{|c|}{ Nilai } & Korelasi \\
\hline 0 & - 0,199 & Sangat rendah \\
\hline 0,200 & - 0,399 & Rendah \\
\hline 0,400 & - 0,599 & Sedang \\
\hline 0,600 & - 0,799 & Kuat \\
\hline 0,800 & - 1,000 & Sangat kuat \\
\hline
\end{tabular}

Dilihat dari nilai korelasi, hampir semua provinsi (kecuali Kepulauan Bangka Belitung, Nusa Tenggara Barat, Kalimantan Timur dan Sulawasi Selatan) memiliki nilai korelasi yang kuat antara PDRB/Kapita dan IPM dengan Investasi.PDRB/Kapita dan IPM tidak memiliki korelasi atau hubungan yang kuat $(<0,60)$ dengan Investasi di Kepulauan Bangka Belitung, Nusa Tenggara Barat, Kalimantan Timur dan Sulawesi Selatan. Hal ini terjadi karena investor tidak melihat kepada kondisi ekonomi dan social melainkan pada sumberdaya alam yang dimiliki oleh Kepulauan Bangka Belitung, Nusa Tenggara Barat, Kalimantan Timur dan Sulawesi Selatan. Kepulauan Bangka Belitung sebagai 
penghasil biji timah terbesar di Indonesia.Biji timah memberi kontribusi yang cukup besar dalam pembangunan nasional.Secara total, produksi biji timah tahun 2005 mencapai 42.615,22 ton Sn dan logam timah sebesar 41.789 metric Sn atau seluas 30\% daratan Pulau Belitung. Nusa Tenggara, Kalimantan Timur dan Sulawesi Selatan mengandalkan sumberdaya lautnya.

PDRB per kapita dan IPM memiliki korelasi atau hubungan yang negatif dengan Investasi di DKI Jakarta, ini berarti PDRB per kapita dan IPM naik tetapi investasi turun.Nilai investasi pada tahun 2012 mengalami penurunan sebesar 24\% dibandingkan tahun 2010.karena ada pergeseran nilai investasi dari DKI Jakarta menuju daerah sekitar seperti Jawa Barat dan Banten. Nilai invetasi di Jawa Barat pada tahun 2012 mengalami peningkatan sebesar 64\% dibandingkan tahun 2010 sedangkan nilai invetasi di Banten pada tahun 2012 mengalami peningkatan sebesar 55\% dibandingkan tahun 2010.

\section{Analisis Infrastruktur}

KPPOD dan BKPM pada tahun 2008 melakukan pemeringkatan iklim usaha 33 provinsi di Indonesia dengan salah satu yang diukur adalah infrastruktur fisik. Pengukuran infrastrukturmeliputiketersediaan, kualitas dan kebijakan tata kelola infrastruktur yangmemungkinkan mobilitas barang dan manusia. Mobilitas diperlukan dalamjenis investasi apa pun karena para pelaku usaha akan lebih fokus pada upaya peningkatan produktivitas perusahaan dan tidak dibebani oleh pelaksanaan kewajiban pemerintah daerah dalam menjamin sarana dan prasarana dasar.

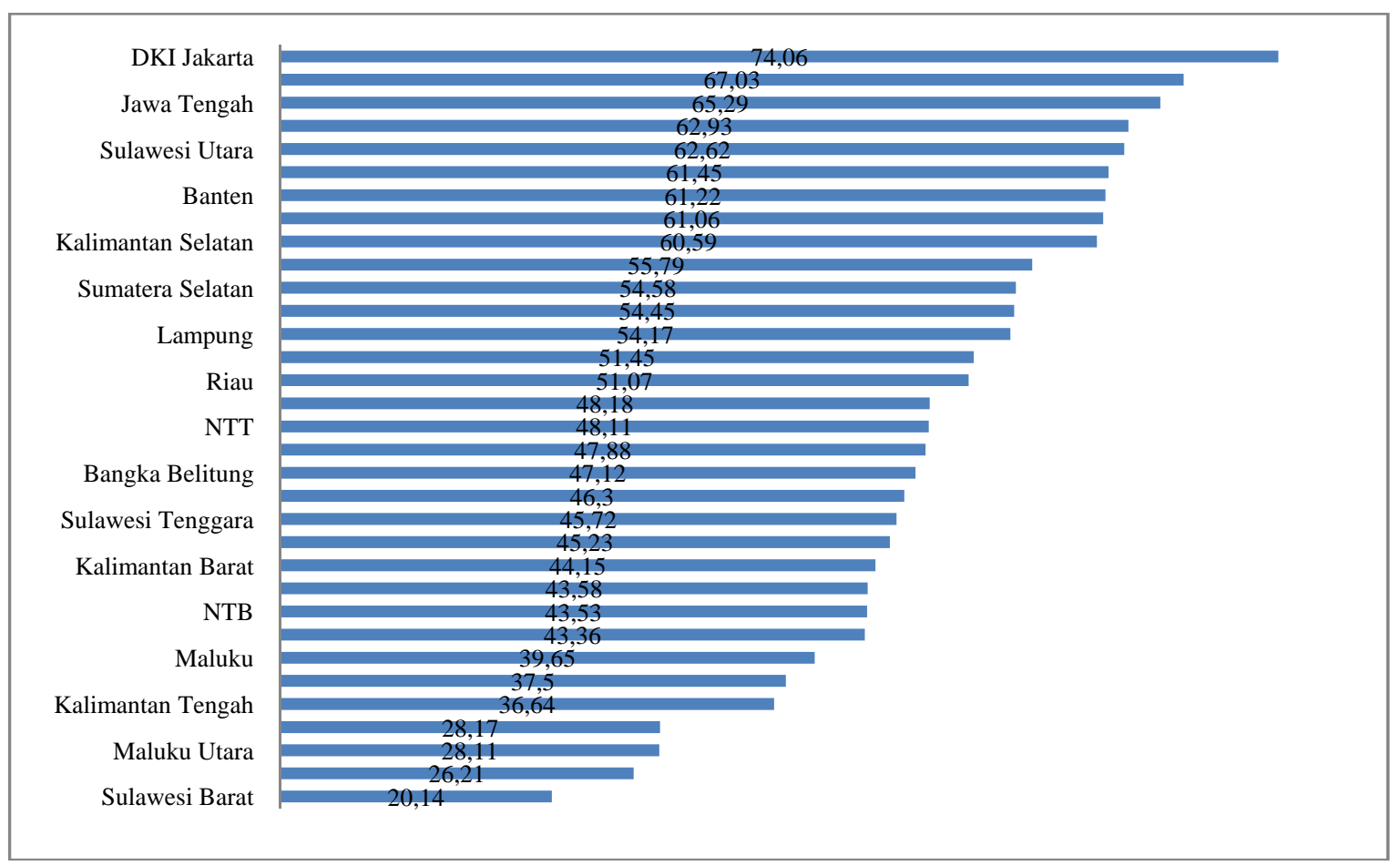

Gambar 2 Indeks Infrastruktur Fisik Sumber: KPPO D dan BKPM

Dilihat dari peringkat Indeks Infrastruktur Fisik, daerah-daerah diJawa dan Bali mendominasi peringkat atas.DKI Jakarta berada pada peringkat pertama untuk indikator infrastruktur diikuti oleh Bali, Jawa Tengah, Jawa Timur, Sulawesi Utara, SulawesiSelatan, Banten, DIY dan seterusnya. Sementara peringkat terbawah ada di daerah-daerah luar Pulau Jawa sepertiSulawesi Barat sebagai Provinsi dengansub-indeks terendah untuk penilaian infrastruktur. 
Dari kualitas sambunganlistrik, masih terlihat belum memadai dengan frekuensi pemadaman listrik yang cukup tinggi.Pengusahamenilai ketersediaan listrik sangat kurang.Untuksarana komunikasi sepertisambungan telepon dan internet,masih banyak desa-desa di provinsi yang belum terpasang sambungan telepon dan internet atauterpasang tapi dengan kualitas yang rendah.

Untuk infrastruktur jalan darat, berdasarkan data statistik infrastruktur dari Depertemen PU tahun 2007-2008, kondisi jalan darat di Indonesia masih cukup memprihatinkan.Dari keseluruhan jalan yang menjadi kewenangan kabupaten/kota, hanya 56\% berkondisi baik, dan sisanya dalam kondisi rusak atau rusak parah. Sedangkan untuk kondisi jalan provinsi sedikit lebih baik, yakni 64,15\% dalam kondisi baik.

\section{Analisis Pengaruh Investasi terhadap PDRB/Kapita, IPM dan Infrastruktur}

Pertama, investasi mendorong pertambahan pendapatan nasional (pertumbuhan ekonomi) secara berlipat ganda lewat proses multiplier. Maksudnya jika ada investasi sebesar Rp. 100 trilyun, maka pertambahan pendapatan nasional akan lebih besar dari Rp. 100 triliun (Nugroho, 2008).Investasi memainkan peran penting dalam menggerakkan kehidupan ekonomi bangsa karena pembentukan modal memperbesar kapasitas produksi, menaikkan pendapatan nasional maupun menciptakanlapangan kerja baru, dalam hal ini akan semakin memperluas kesempatan kerja (Todaro, 2003).

Kedua, investasi juga akan mendorong penciptaan lapangan kerja. Penciptaan lapangan kerja ini akan mengurangi pengangguran. Berkurangnya pengangguran akan mengurangi kemiskinan dan berkurangnya kemiskinan akan mengatasi masalah-masalah yang terikutkan seperti gizi buruk, buta huruf, kejahatan dan lain-lain sehingga tingkat IPM semakin meningkat.

Ketiga, infrastruktur yang baikakan digunakan untuk menopang keberlangsungan kegiatan perusahaan sehingga dapat menekan inefisiensi dari aktivitas masyarakat dan meningkatkan pertumbuhan ekonomi.

\section{SIMPULAN}

Investasi daerah di Indonesiamasih terfokus di Pulau Jawa.Data menunjukkan sebesar $60 \%$ investasi berada di Pulau Jawa.Hal ini menunjukkan bahwa tidak adanya distribusi investasi secara merata di Indonesia.Dilihat dari persentasi total investasi di Indonesia, persentasi terbesar berada di DKI Jakarta dan selanjutnya diikuti oleh Jawa Barat, Jawa Timur dan Banten secara bergantian.Hampir semua Provinsi (kecuali Kepulauan Bangka Belitung, Nusa Tenggara Barat, Kalimantan Timur dan Sulawasi Selatan) memiliki nilai korelasi yang kuat antara PDRB/Kapita dan IPM dengan Investasi.

PDRB/Kapita dan IPM memiliki korelasi atau hubungan yang negatif dengan Investasi di DKI Jakarta.Artinya PDRB/Kapita dan IPM naik tetapi investasi turun.Terjadi penurunan nilai investasi pada tahun 2012 sebesar 24\% dibandingkan tahun 2010.Hal ini dikarenakan ada pergeseran nilai investasi dari DKI Jakarta menuju daerah sekitarnya seperti Jawa Barat dan Banten.Investasi yang masih terfokus di Pulau Jawa ini dikarenakan PDRB/Kapita, IPM dan infrastruktur lebih baik dibandingkan di luar Pulau Jawa. 


\section{DAFTAR PUSTAKA}

Ali, S., Guo,W. (2005). Determinant of FDI in China.Journal of Global Business and Technology, $1(2)$.

BKPM.(2008). Peningkatan Iklim Investasi 33 Provinsi di Indonesia Tahun 2008.Diakses dari http://www.bkpm.go.id

KPPOD.(2003). DayaTarik Investasi Kabupaten/Kota di Indonesia. Jakarta: KPPOD.

Nugroho, S. B. M. (2008).Evaluasi Terhadap Faktor-Faktor yang Mempengaruhi Investasi di Indonesia danImplikasi Kebijakannya.Jurnal Riptek, 2(1): 18-21.

Sodik, J., Nuryadin, D. (2006). Investasi dan Pertumbuhan Ekonomi Regional (Studi Kasus Pada 26 Propinsi di Indonesia, Pra dan Pasca Otonomi).Jurnal Ekonomi Pembangunan: 157-170.

Sukirno, S. (1994).Pengantar Teori Ekonomi Makro. PT. Jakarta: Raja Grafindo Persada.

Sugiyono.(2007). Statistika untuk Penelitian. Bandung: CV. Alfabeta.

Tambunan, T. H. T.(2001).Transformasi Ekonomi di Indonesia, Teori \& Penemuan Empiris. Penerbit Jakarta: Salemba Empat.

Todaro, M. P. (2000).EconomicDevelopment.(7 ${ }^{\text {th }}$ edition). Addison Wesley.

United Nations Development Programme.(1995). Human Development Report 1995.Published for United Nations Development Programme. New York: Oxford University Press. 